\title{
Profile of Head and Neck Cancers in Dr. Lütfi Kırdar Kartal Educational and Research Hospital
}

\author{
Dr. Lütfi Kırdar Kartal Eğitim ve Araştırma Hastanesi \\ Baş Boyun Kanserleri Profili
}

\author{
Kayhan BAŞAK, Yasin SAĞLAM, Ayşe Gökçen YILDIZ, Merve BAŞAR, Hanım İstem KÖSE, \\ Şükran KAYIPMAZ, Nimet KARADAYI
}

Department of Pathology, Dr. Lütfi Kırdar Kartal Education and Research Hospital, ISTANBUL, TURKEY

\section{ABSTRACT}

Objective: Head and neck cancers account for $17.6 \%$ of all malignant neoplasms. Data on the incidence of head and neck cancers and histological subtypes in Turkey are limited. This study aimed to provide an overview of statistics for head and neck cancers.

Material and Method: This retrospective and descriptive study included 1973 cases of in-situ carcinomas, malignant and borderline neoplasia from the head and neck region in a period of 5 years, diagnosed at Dr.Lütfi Kirdar Kartal Education and Research Hospital's Department of Pathology. Demographic data of patients and data from histopathological report were recorded. The topography of all tumours was coded according to the International Classification of Diseases for Oncology, 2nd and 3rd edition and histological and behavioral codes were given according to ICD-O-3. Data was entered and analyzed using Microsoft Excel ${ }^{\mathrm{mix}}$, version 2010.

Results: Male and female ratio was 1.03 for head and neck cancers. The most common sites for males were described as the ratio in head and neck cancers and all malignant tumours as follows: the skin (non-melanoma) (48.4\%-8.2\%), the larynx (12.6\%-2.3\%), the thyroid (11.1\%-1.2\%), the lips (7.8\%-1.3\%), and the nasopharynx (3.1\%-0.5\%). The most common sites for females were as follows: the thyroid (45.3\%-8.3\%), the skin (non-melanoma) (39.6\%-7.3\%), the lips $(3.6 \%-0.6 \%)$, the nasopharynx $(2.2 \%-0.4 \%)$ and the eye $(1.7 \%-0.3 \%)$. The male: female ratio was 25.2 for larynx cancers. The most common histological types and rates for males and females were also given.

Conclusion: This descriptive epidemiological pathology-based cancer incidence study has relative value for describing head and neck cancer incidences in the İstanbul region and shown that pathology report-based descriptive epidemiological studies are still valuable for determination of the regional distribution of cancer incidence out of the active cancer registration regions.

Key Words: Head and neck cancers, Epidemiology, Histology, Turkey

\section{öz}

Amaç: Baş boyun tümörleri tüm malign neoplazmların \%17,6’sını oluşturmaktadır. Türkiyedeki baş boyun kanserleri insidansları ve histolojik alt tiplerine ait bilgiler sınırlıdır. Bu çalışma baş boyun kanserleri istatistiklerine genel bakışı amaçlamaktadır.

Gereç ve Yöntem: Retrospektif ve deskriptif olan çalışma, Dr. Lütfi Kırdar Kartal Eğitim ve Araştırma Hastanesi Patoloji Kliniği’nde 5 yıllık zaman diliminde tanı alan, baş boyun bölgesine ait 1973 in-situ karsinom, malign ve borderline neoplazi olgusunu içermektedir. Hastalara ait nüfus bilgileri ve histopatoloji raporlarındaki bilgiler kaydedildi. Tüm tümörlere ait topoğrafi kodlaması Uluslararası Hastalıkların Sinıflandırılması-Onkoloji 2. ve 3. baskılara göre, histoloji ve davranış kodlaması 3. baskıya göre yapılmıştır. Veri kayıtları ve analizi Microsoft Excel ${ }^{\mathrm{Tm}}$, 2010 versiyonu ile yapılmıştır.

Bulgular: Erkek ve kadın oranı 1,03'dür. Erkeklerde en sık görülen lokalizasyonların, baş boyun tümörleri içinde ve tüm tümörler içinde dağılımı şu şekildedir; deri (melanom dışı) (\%48,4-\%8,2), larinks (\%12,6-\%2,3), tiroid (\%11,1-\%1,2), dudak (\%7,8-\%1,3) ve nazofarinks (\%3,1-\%0,5). Kadınlarda en sık görülen lokalizasyonların, baş boyun tümörleri içinde ve tüm tümörler içinde dağılımı şu şekildedir; tiroid (\%45,3-\%8,3), deri (melanom dışı) (\%39,6-\%7,3), dudak (\%3,6-\%0,6), nazofarinks $(\% 2,2-\% 0,4)$ ve göz $(\% 1,7-\% 0,3)$. Larinks kanserleri için erkek kadın oranı 25,2 dir. Erkeklerde ve kadınlarda en çok görülen histolojik tip ve oranları da ayrıca verildi.

Sonuç: Patoloji rapor tabanlı retrospektif deskriptif epidemiyolojik çalışmamız İstanbul bölgesi baş boyun kanserleri oranlarını belirlemede göreceli değer taşımakta ve patoloji rapor-tabanlı deskriptif epidemiyolojik çalışmaların, aktif kanser kayıt bölgelerinin dışında kanser insidansı bölgesel dağılımının belirlenmesi için değerli olduğunu göstermektedir.

Anahtar Sözcükler: Baş boyun kanserleri, Epidemiyoloji, Histoloji, Türkiye
(Turk Patoloji Derg 2015, 31:119-125)

Received : 08.06.2014 Accepted : 06.08.2014
Correspondence: Kayhan BAŞAK

Dr. Lütfi Kırdar Kartal Eğitim ve Araştırma Hastanesi, Patoloji Bölümü, Şemsi Denizer Cad. E-5 Karayolu Cevizli Mevkii,

34890 Kartal, İSTANBUL, TURKEY

E-mail: drkayhanbasak@yahoo.com Phone: + 902164413900 / 1054 


\section{INTRODUCTION}

Data on the incidence of cancers and histological subtypes in Turkey are limited. The studies for determination of cancer incidences dominantly describe topographical distribution according to organs or tissues. For determination of priority in cancer control studies, estimated rate of new cancers and estimated deaths caused by cancer must be predicted. In Turkey, the Cancer Registration System and death declaration system (Republic of Turkey Ministry of Health, Directorate of Public Health) are primary systems to collect cancer data. The death declaration system also provides survival information for each special type of cancer (1).

Histopathological verification of new case records in registration center is crucial. In addition, advances in molecular pathology and targeted therapies in many organs requires identifying and determining the rates of histological types.

The Republic of Turkey Ministry of Health started a passive cancer registration system at 1983 (2). The active cancer registration system first was to be built in the İzmir province in 1992. There are 15 active cancer registration centers in Turkey that are located in the provinces of Antalya (1998), Bursa (2000), Eskişehir (2000), Samsun (2001), Trabzon (2003), Edirne (2004), Erzurum (2005), Ankara (2006), Kocaeli (2007), Gaziantep (2010), Malatya (2010), Mersin (2012), İstanbul (2012), and Adana (2012). These fifteen cancer registration centers comprise more than $50 \%$ of the population in Turkey (1). Active registration results were first reported in 2002 and data included in "Cancer Incidence in Five Continents" (3).

\section{MATERIALS and METHODS}

This retrospective and descriptive study included 1973 biopsy-proven cases of all in-situ carcinomas, malignant and borderline neoplasia from the head and neck region diagnosed at Dr.Lütfi Kırdar Kartal Education and Research Hospital (KEAH), Department of Pathology, İstanbul, Turkey. Permission was granted from the ethics committee of KEAH to review the pathology archive records of the Department of Pathology. 150.035 histopathological and cytopathological report records were reviewed in archives of the Pathology Department, within a period of 5 years from January 2008 to December 2012. During five year period, 7.846.143 patients admitted to KEAH, 202.424 hospitalized, 150.035 pathological material examined and 11.189 cancer included 1.973 head and neck region cancers (HNCs) were diagnosed.

Data about the Turkish personal identification number, date of diagnosis, pathology laboratory record number, age, gender, the exact site of the tumour and histological diagnosis from pathology laboratory were recorded. The topography of all tumours was coded according to the International Classification of Diseases for Oncology, 2nd and 3rd edition (4) (ICD-O-2 and ICD-O-3) in 3 and 4 digits. Histological and behavioral codes were given according to ICD-O-3. Data was entered and analyzed using Microsoft Excel ${ }^{\mathrm{m}}$, version 2010. All records were sorted by Turkish personal identification number, pathology report number, date of pathological diagnosis, topography and histological diagnosis. Repeated records that belong to the same patient's same tumours were sorted out and different tumours at a different site were recorded separately. Local recurrence and distant metastasis were considered.

\section{RESULTS}

A total of 1973 biopsy proven cases of head and neck cancer (HNC) were seen during the study period. The mean age of the patients was 57.9 years. The mean age of male patients was 59.9 (range 3-99) years and the mean age of female patients was 56.2 (range 2-98) years. The male to female ratio was 1.026 (number of males: 999 and females: 974).

The most common sites for males were the skin (nonmelanoma skin cancers) (48.4\%), larynx (12.6\%), thyroid (11.1\%), lips (7.8\%) and nasopharynx (3.1\%). The most common sites for the females were the thyroid (45.3\%), skin (non-melanoma skin cancers) (39.6\%), lip (3.6\%), nasopharynx (2.2\%) and the eye (1.7\%) (Table I).

Age distribution for both sexes is shown in Figure 1 and the most common histological types in both genders are shown in Table II.

Sixty cases had multiple tumours; 41 cases had 2 tumours, 16 cases had 3 tumours, 2 cases had 4 tumours and 1 case had five tumours. The mean age of cases at the time of initial tumour diagnosis was 62.9 years and the ages ranged between 26 and 93 years. Thirty-one cases were male and 29 cases were female. Time intervals were 1.8 years, 1.9 years, 1.5 years and 1 year for the second, third, fourth and fifth primary tumours, respectively.

\section{DISCUSSION}

Dr.Lütfi Kirdar Kartal Education and Research Hospital's (KEAH) receives $87.8 \%$ of its patient population from İstanbul and $4.4 \%$ from Kocaeli province, so our data predominantly represent the cancer distribution of İstanbul. During the study period, a total of 7.846 .143 patients applied to KEAH and 11.189 new cancer cases were diagnosed.

There was a female predominance between the age 15 and 49 years, and male predominance after age 50 as shown 
Table I: Most frequent topographical sites for gender

\begin{tabular}{|c|c|c|c|}
\hline \multicolumn{4}{|c|}{ Male } \\
\hline & Topography & Number & $\%$ \\
\hline 1 & *Skin head and neck & 484 & 48.4 \\
\hline 2 & Larynx & 126 & 12.6 \\
\hline 3 & Thyroid & 111 & 11.1 \\
\hline 4 & Lip & 78 & 7.8 \\
\hline 5 & Nasopharynx & 31 & 3.1 \\
\hline 6 & Nose, sinuses etc. & 27 & 2.7 \\
\hline 7 & Tongue & 25 & 2.5 \\
\hline 8 & $\begin{array}{l}\text { Connective and soft tissue of } \\
\mathrm{H} \& \mathrm{~N}\end{array}$ & 23 & 2.3 \\
\hline 9 & Hypopharynx & 18 & 1.8 \\
\hline 10 & Tonsil & 15 & 1.5 \\
\hline 11 & Eye & 14 & 1.4 \\
\hline 12 & Parotid Gland & 13 & 1.3 \\
\hline 13 & Salivary glands & 9 & 0.9 \\
\hline 14 & Mouth & 7 & 0.7 \\
\hline 15 & Other oropharynx & 7 & 0.7 \\
\hline
\end{tabular}

\begin{tabular}{|c|l|c|c|}
\hline \multicolumn{2}{|l|}{ Female } & Number & $\%$ \\
\hline 1 & Topography & 441 & 45.3 \\
\hline 2 & Thyroid & 386 & 39.6 \\
\hline 3 & Lip & 35 & 3.6 \\
\hline 4 & Nasopharynx & 22 & 2.2 \\
\hline 5 & Eye & 17 & 1.7 \\
\hline 6 & Tongue & 10 & 1.0 \\
\hline 7 & Parotid Gland & 9 & 0.9 \\
\hline 8 & Nose, sinuses etc. & 9 & 0.9 \\
\hline 9 & Connective and soft tissue of H\&N & 9 & 0.9 \\
\hline 10 & Salivary glands & 8 & 0.8 \\
\hline 11 & Hypopharynx & 7 & 0.7 \\
\hline 12 & Larynx & 5 & 0.5 \\
\hline 13 & Mouth & 4 & 0.4 \\
\hline 14 & Tonsil & 4 & 0.4 \\
\hline 15 & Trachea & 4 & 0.4 \\
\hline
\end{tabular}

${ }^{*}$ Non-melanoma skin cancers.

Table II: Most common histological types and rates in the head and neck region

\begin{tabular}{|l|c|}
\hline Male & \% \\
\hline Squamous cell carcinoma-NOS & 33.5 \\
\hline Basal cell carcinoma-NOS & 31.3 \\
\hline Carcinoma-NOS & 5.8 \\
\hline Papillary adenocarcinoma-NOS & 5.0 \\
\hline Malignant lymphoma & 5.0 \\
\hline
\end{tabular}

\begin{tabular}{|l|c|}
\hline Female & \% \\
\hline Papillary adenocarcinoma-NOS & 35.6 \\
\hline Basal cell carcinoma-NOS & 30.1 \\
\hline Squamous cell carcinoma-NOS & 11.0 \\
\hline Malignant lymphoma & 3.9 \\
\hline Follicular adenocarcinoma-NOS & 3.8 \\
\hline
\end{tabular}

in Figure 1. 89.7\% of cases were between 35 and 84 years. According to the 2012 population of Turkey (5), the group older than 80 years made up $1.5 \%$ of all the population, and $\mathrm{HNC}$ in this age group was $9.1 \%$. The group aged $35-$ 79 years made up $39.9 \%$ and $\mathrm{HNC}$ in this age group was $83.3 \%$. Those under 34 years made up $58.5 \%$ and the rate of $\mathrm{HNC}$ in this age group was $7.6 \%$.

Many histopathological report-based studies have been performed in Turkey before the Active Cancer Registration Centers were established (1,7-27). Thirteen studies included 149.647 cancer records reviewed for an incidence rate of special topographic sites of the head and neck region $(8,9,12-15,19,22-27)$ (Table III). Many of these studies describe the cancer profile in Turkey before active cancer recording. Table IV provides a summary of valuable data

from these studies. It is obviously seen that these reports have no standardization. Most of these studies did not use coding topography or histology according to ICD-O (1215,20-22,27) and did not document the rate of incidence of special topographic sites cancers separately, They therefore do not include or have only limited data regarding the rate of cancer incidence of special topographic sites of the head and neck region $(8,14,20,22-26)$. A limited number of studies used ICD-O coding for topography and histology and described rates for all sites including specific topographic sites of the head and neck $(9,19,25)$. Burgut et al. reported one of the first results coded with ICD-O and described frequencies according to organ and system groups (8).

Data for the most frequent head and neck region cancers from the Republic of Turkey Ministry of Health, 


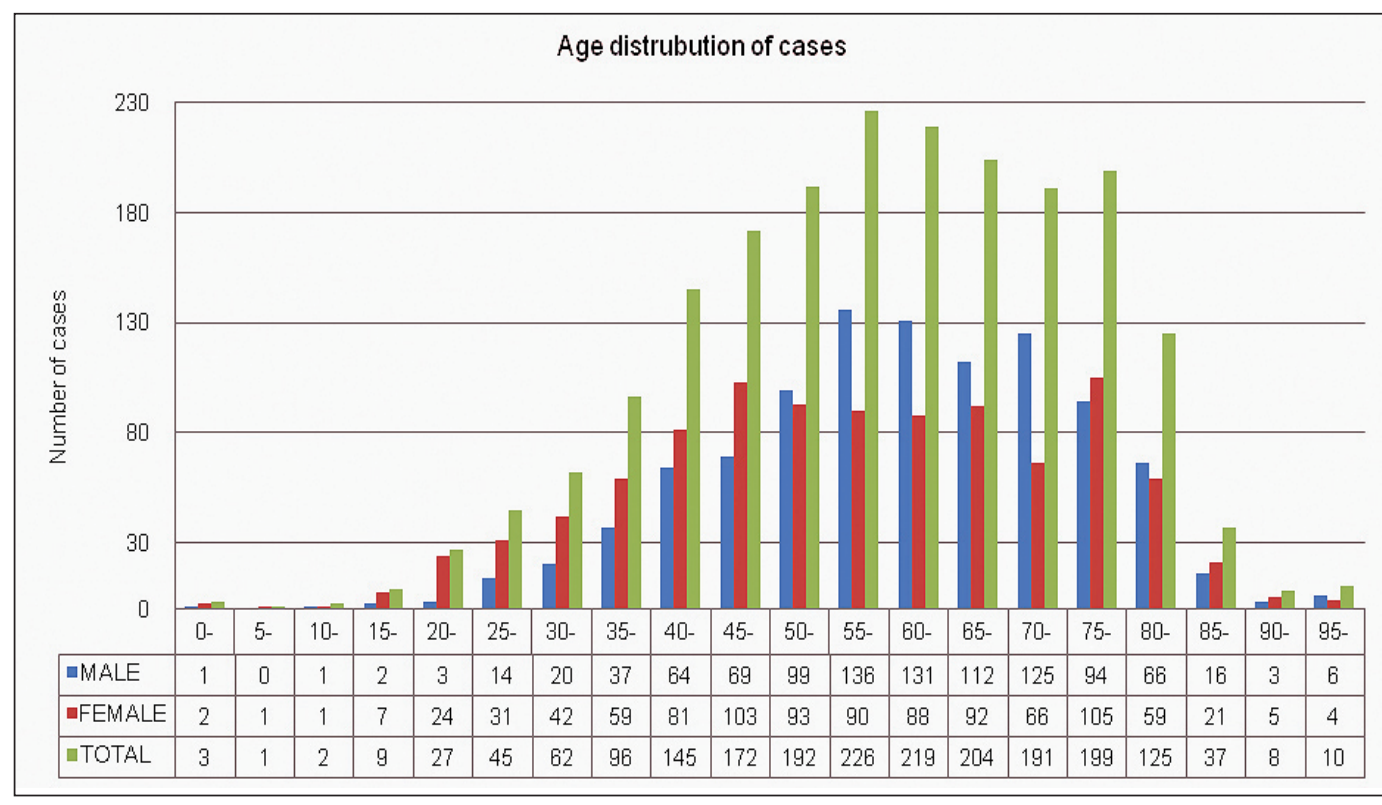

Figure 1: Distribution of all head and neck malignancies in 20 age group by gender.
Directorate of Public Health 2009 (1) and KEAH 20082012 are presented in Table V. The first six most frequent cancer topography in males and first five most frequent cancer topography in females are similar. The six studies with valuable information on HNC rates also show a high rate of similarity with data from the Turkey cancer statistics in 2009 (1).

The expected rate of people older than 50 years in Turkey is $10.2 \%$ for the year 2023 and $20.8 \%$ for the year 2050 (1). Data on the incidence of HNCs and histological subtypes in Turkey are limited. It is important to document cancer distribution findings about time trends and variations in incidence, mortality and survival. In 1998, cancer was the second leading cause of death in Turkey (15.4\%) while the leading cause of death was cardiovascular diseases (2). In 2012, cancer was still the second leading cause of death (21.1\%) (5,28). According to the Turkey's 2013 Health Statistics Yearbook from the Ministry of Health, the incidence of cancer is 281.6 cases per 100.000 people (29).

In conclusion, this cancer incidence study based on descriptive epidemiological pathology reports has relative value for describing HNC incidences and represents the İstanbul region. The cancer incidence of topographical sites was similar in incidence to the Turkish literature and data from the Directorate of Public Health. Pathology reportbased descriptive epidemiological studies are still valuable for determination of the regional distribution of cancer incidence out of the active cancer registration regions.

\section{REFERENCES}

1. Republic of Turkey Ministry of Health, Directorate of Public Health. Online Edition: “Türkiye kanser istatistikleri” [updated 2014; cited 2014 May]. Available from:http://kanser.gov.tr/dairefaaliyetleri/kanser-istatistikleri.html

2. Türk Kanser Araştırma ve Savaş Kurumu Derneği. http://www. turkkanser.org.tr/ Online Edition: Türkiyede Kanser İstatistikleri. [updated 2006; cited 2014 May]. Available from: http:// www.turkkanser.org.tr/dosyalar/istatistikler/turkiye-kanseristatistikleri.pdf

3. Kanserle Savaş Politikası ve Kanser Verileri (1995-1999). Ankara: T.C. Sağlık Bakanlığı Kanserle Savaş Dairesi Başkanlığı; 2002.

4. Fritz A, Percy C, Jack A, et al. International Classification of Diseases for Oncology. 3rd ed. Geneva: World Health Organization; 2000.

5. Türkiye İstatistik Kurumu. Ankara, Türkiye İstatistik Yıllığı 2012. Ankara: Türkiye İstatistik Kurumu Matbaası; 2013.

6. Bilir N. Cancer frequency in Turkey. Kanser. 1981;11:93-7.

7. Bilir N. Cancer occurence in developing countries. In: Parkin DM, editors. Turkey. Lyon: IARC; 1986. 303-7.

8. Burgut R, Tuncer İ, Bozdemir N, Özoran Y, Karagöz F, Uzgören E, Kutlu K, Başak K, Eğilmez R, Aydın E, Arslan A, Yumbul Z, Yeğin G, Yurdal M, Akçalı İP, Bakır K, Ünalp A. Türkiye’de 16 merkezin kanser verilerinin değerlendirilmesi. Adana: TÜBİTAK ve Çukurova Üniversitesi Tip Fakültesi; 1994. 27-66.

9. Başak K, Aksoy F. Ankara Numune Hastanesi'nde 19841992 Yılları arasındaki kanser dağılımının değerlendirilmesi. Deskriptif epidemiyolojik bir çalışma. Ankara Patoloji Bülteni. 1993;10:62-71.

10. Kösem M, Bayram İ. Van yöresindeki ekstremite kemik ve yumuşak doku tümörlerinin dağılımı ve değerlendirilmesi. Van Tip Dergisi. 2001;8:93-6. 
Table III: Pathology report based descriptive studies.

\begin{tabular}{|c|c|c|c|c|c|c|c|c|c|c|c|c|c|c|c|c|c|c|c|c|c|c|c|c|c|c|}
\hline & \multicolumn{13}{|c|}{ Male } & \multicolumn{13}{|c|}{ Female } \\
\hline & 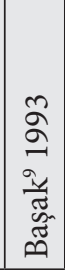 & 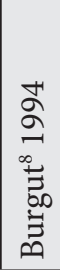 & 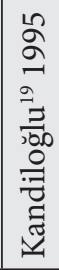 & 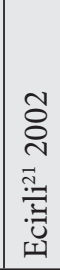 & 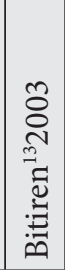 & 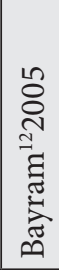 & 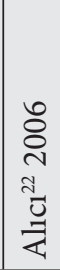 & 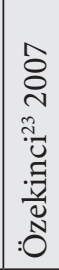 & 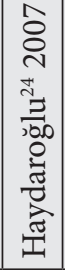 & 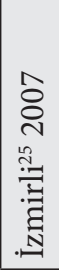 & 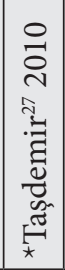 & 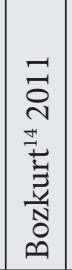 & 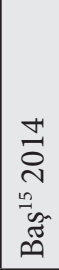 & 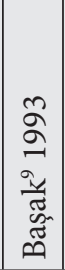 & 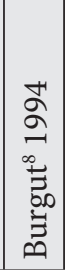 & 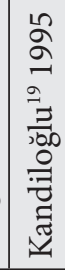 & 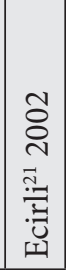 & 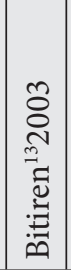 & 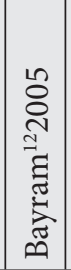 & 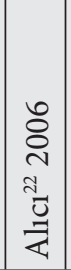 & 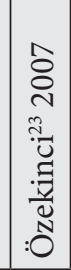 & 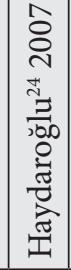 & 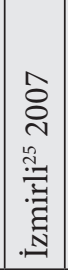 & 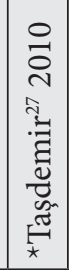 & 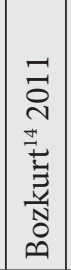 & 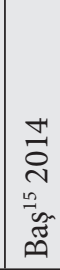 \\
\hline Anorectal & 2.6 & & & & & & & & & & & & & 3.0 & & & & & & & & & & & & \\
\hline Bone & 2.3 & & & & & & & & & & & & & 2.9 & & & & & & & & & & & & \\
\hline Bone and STS & & & & & & & & & 3.3 & & & & & & & & & & & & & 2.9 & & & & \\
\hline Bone marrow & & & & & & & & & & & & & & & & & & & & & & & & 7.5 & & \\
\hline Brain & 5.7 & 2.9 & 2.4 & & & & & & 5.8 & & & & & 4.5 & 2.6 & & & & & & & 5.5 & & & & \\
\hline Brain - CNS & & & & & & & & & & 3.9 & & & & & & & & & & & & & 3.1 & & & \\
\hline Breast & & & & & & & & & 0.3 & & & & & 14.2 & 23.2 & 18.3 & \begin{tabular}{|l|}
15.7 \\
\end{tabular} & 22.2 & 9.4 & 52.5 & 10.2 & 26.2 & 33.4 & 21.8 & 15.5 & 19.2 \\
\hline C. Uteri & & & & & & & & & & & & & & \begin{tabular}{|l|}
1.9 \\
\end{tabular} & 3.7 & \begin{tabular}{|l|}
9.9 \\
\end{tabular} & & & & & & & \begin{tabular}{|l|}
4.8 \\
\end{tabular} & & & 1.1 \\
\hline CNS & & & & 7.9 & & & & & & & & & & & & & 10.3 & & & & & & & & & \\
\hline Colon & 2.3 & & & 7.6 & & & & & & & & & & 3.4 & & 2.1 & 8.0 & & & & & & & & & \\
\hline Colorectal & & & & & & & 13.6 & & & \begin{tabular}{|l|l|}
8.8 \\
\end{tabular} & & 12.9 & 5.5 & & & & & & & 9.4 & & & 8.3 & & 7.8 & 7.8 \\
\hline Cp. Uteri & & & & & & & & & & & & & & & 2.5 & & & & & & & & & & & \\
\hline Esophagus & & & 2.1 & & & 9.4 & & & & & 12.6 & 4.8 & 1.2 & & & & & & 16.9 & & & & & 23.1 & 2.2 & \\
\hline Eye & & & & & & & & & 0.3 & & & & & & & & & & & & & 0.5 & & & & \\
\hline Gall bladder & & & & & & & & & & & & & & 2.2 & & & & & & & & & & & & 1.7 \\
\hline Gen-NOS & & & & & & & & & 5.3 & & & & & & & & & & & & & 20.0 & & & & \\
\hline GIS-NOS & & & & & & & & & 13.7 & & & & & & & & & & & & & 14.3 & & & & \\
\hline Head and neck & & & & & & & 6.1 & & 12.6 & & & & & & & & & & & 2.3 & & \begin{tabular}{|l|}
5.6 \\
\end{tabular} & & & & \\
\hline Heamopoietic & & & & 8.4 & & & & & 4.3 & & & & & & & & 8.2 & & & & & 4.1 & & & & \\
\hline $\mathrm{HL}$ & 1.4 & & & & & & 5.1 & & & & & & & & & & & & & & & & & & & \\
\hline Kidney & & & 2.3 & & & & & & & & & & & & & & & & & & & & & & & \\
\hline Larynx & 9.6 & 7.8 & 20.0 & 5.6 & 10.3 & & & & & 4.1 & & & & & & 0.8 & & & & & & & & & & \\
\hline Lip & 4.8 & & 2.5 & & & & & & & & & & & & & 1.1 & & & & & & & & & & \\
\hline Liver & 1.8 & & & & & & & & & & & & & 2.3 & & & & & & 2.2 & & & & & & \\
\hline LN & & & & & & & & 12.8 & 2.8 & & & & & & & & & & & & 9.7 & 1.9 & & & & \\
\hline Lung & 1.8 & 5.6 & & 25.1 & 11.1 & \begin{tabular}{|l|}
7.3 \\
\end{tabular} & 26.6 & 8.9 & 27.5 & 36.1 & 11.6 & & 3.1 & & & & 7.6 & & & 4.5 & & & 4.9 & & & \\
\hline Lymphoma & & 3.4 & 4.6 & 4.3 & \begin{tabular}{|l|}
6.7 \\
\end{tabular} & & & & & & & & & & \begin{tabular}{|l|}
2.9 \\
\end{tabular} & 1.6 & 6.4 & & & & & & & & & \\
\hline Nasopharynx & & & 1.3 & & & & & & & & & & & & & & & & & & & & & & & \\
\hline NHL & 2.3 & & & & & & 7.1 & & & 4.0 & & & & 2.3 & & & & & & 3.8 & & & 3.2 & & & \\
\hline Oral cavity & & 5.7 & & & & & & & & & & & 2.5 & & & & & & & & & & & & & \\
\hline Ovary & & & & & & & & & & & & & & \begin{tabular}{|l|}
3.2 \\
\end{tabular} & 3.5 & 7.2 & 7.2 & 6.2 & & 3.8 & & & 6.0 & & & \\
\hline Pancreas & & & & 3.6 & & & & & & & & & & & & & & & & 2.8 & & & & & & \\
\hline Prostate & 6.0 & 4.0 & 7.2 & 4.1 & & & 3.2 & & & 3.9 & & & 23.4 & & & & & & & & & & & & & \\
\hline Rectum & & & 2.6 & & & & & & & & & & & & 2.9 & 2.4 & & & & & & & & & & \\
\hline R-NOS & & & & & & & & & & & & & & & & & & & & & & 3.2 & & & & \\
\hline Skin & 21.1 & 22.6 & 17.8 & & & 11.7 & 2.5 & 15.4 & \begin{tabular}{|l|}
9.9 \\
\end{tabular} & & 9.4 & 41.9 & 30.3 & 21.6 & 20.3 & 15.0 & 5.0 & & 8.5 & 2.2 & 15.0 & 9.6 & & & 44.4 & 38.4 \\
\hline Soft tissues & 3.6 & & & & & & & & & & & & & 3.7 & & & & & & & & & & & & \\
\hline Stomach & 7.5 & 6.1 & 4.7 & 10.5 & \begin{tabular}{|l|}
9.2 \\
\end{tabular} & 20.2 & 8.5 & 7.6 & & 7.2 & 29.3 & 11.2 & 11.5 & 5.6 & 3.6 & 1.6 & 7.3 & 9.7 & 14.5 & 5.6 & 6.0 & & 4.5 & 13.8 & & 5.4 \\
\hline STS & & 3.6 & 1.4 & & & & 3.2 & & & \begin{tabular}{|l|}
1.7 \\
\end{tabular} & & & \begin{tabular}{|l|}
1.6 \\
\end{tabular} & & \begin{tabular}{|l|}
3.7 \\
\end{tabular} & 1.5 & & 6.0 & & & & & & & & 1.1 \\
\hline Testis & & & 2.4 & & & & 7.3 & & & 2.3 & & & 1.3 & & & & & & & & & & & & & \\
\hline Thyroid & & & \begin{tabular}{|l|}
1.8 \\
\end{tabular} & & & & & & & & & 6.4 & & 7.7 & & 6.3 & & 8.1 & \begin{tabular}{|l|}
8.0 \\
\end{tabular} & & 6.6 & & 6.9 & 10.8 & 20.0 & 12.6 \\
\hline Unknown P & & & & & & & & & 4.3 & & & & & & & & & & & & & 2.9 & & & & \\
\hline Uri.B & 9.4 & 7.4 & 20.8 & 6.9 & 17.5 & 9.8 & & 8.5 & & 2.8 & 8.8 & & 12.9 & 1.5 & & 2.3 & & & & & & & & & & 2.3 \\
\hline Uri-NOS & & & & & & & & & 8.2 & & & & & & & & & & & & & 1.9 & & & & \\
\hline Uterus & & & & & & & & & & & & & & & & \begin{tabular}{|l|}
20.4 \\
\end{tabular} & 5.6 & & & & & & 5.5 & & & 4.4 \\
\hline Vulva & & & & & & & & & & & & & & & & \begin{tabular}{|l|}
1.4 \\
\end{tabular} & & & & & & & & & & \\
\hline
\end{tabular}

Uri.B: Urinary bladder, NHL: Non-Hodgkin Lymphoma, HL: Hodgkin Lymphoma, LN: Lymph Node NOS, STS: Soft tissues sarcomas, R-NOS: Respiratory System NOS, GIS-NOS: Gastrointestinal System NOS, Uri-NOS: Urinary System NOS, CNS: Central Nervous System, H\&N: Head and Neck, Gen-NOS: Genital System NOS, Unknown P.: Unknown Primary, C. Uteri: Cervix Uteri, Cp. Uteri: Corpus uteri.

${ }^{*}$ Mean percentage of year 2006 and $2007^{27}$. 
Table IV: Head and neck cancers percentage and frequency in all cancers in pathology report based descriptive studies.

\begin{tabular}{|c|c|c|c|c|c|c|c|c|c|c|c|c|}
\hline & \multicolumn{6}{|c|}{ Male } & \multicolumn{6}{|c|}{ Female } \\
\hline & 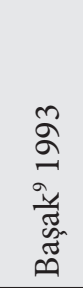 & 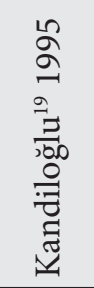 & 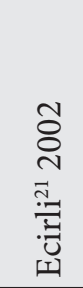 & 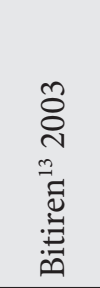 & 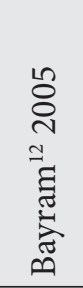 & 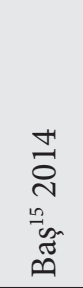 & 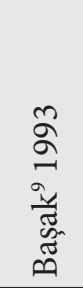 & 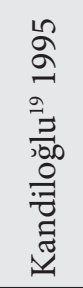 & 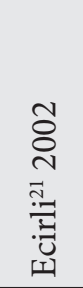 & 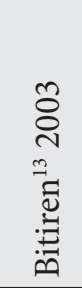 & 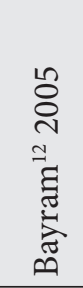 & 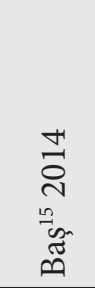 \\
\hline Ear & & 0.15 & & & & & & 0.26 & & & & \\
\hline Eye & & 0.30 & & & & & & 0.52 & & & & \\
\hline Larynx & 9.61 & 12.42 & 5.57 & 10.25 & 4.87 & 0.54 & 0.37 & 0.78 & & 0.19 & 1.30 & \\
\hline Lip & 4.82 & 0.23 & & & 2.02 & & 1.49 & 1.12 & & & 1.12 & \\
\hline Nasal Cavity & 0.82 & & & & & & 0.63 & & & & & \\
\hline Nasopharynx & 0.80 & 1.07 & 0.68 & & 1.50 & 0.85 & 0.78 & 0.35 & 1.05 & & 1.48 & 0.34 \\
\hline Oral & 0.41 & & & & 0.73 & & 0.60 & & & & 0.77 & \\
\hline Oral Cavity-Lip included & & & & & & 2.56 & & & & & & 1.89 \\
\hline Oral Cavity-Nasopharynx & & & & 1.78 & & & & & & 3.86 & & \\
\hline Oropharynx & 0.07 & & & & 0.20 & & & & & & 0.35 & \\
\hline Palate & 0.30 & & & & 0.16 & & 0.26 & & & & & \\
\hline Paranasal sinuses & & 0.3 & & & & & & 0.09 & & & & \\
\hline Salivary gland & 0.32 & 0.23 & & & 0.32 & & 0.48 & 0.52 & & & 0.71 & \\
\hline Thyroid & 1.05 & 1.37 & 0.86 & 1.63 & 1.42 & 0.7 & 7.74 & 6.31 & 1.33 & 8.11 & 8.00 & 12.64 \\
\hline Tongue & 0.52 & & & & & & 0.3 & & & & & \\
\hline
\end{tabular}

Table V: Comparison of most frequent head and neck region cancer rates in data from the Republic of Turkey Ministry of Health, Directorate of Public Health 2009 (1) and KEAH 2008-2012.

\begin{tabular}{|l|l|c|}
\hline & Turkey 2009' & $*$ \\
\hline Larynx & 8.1 \\
\hline Oral. Pharynx & 6.4 \\
\hline Thyroid & 4.5 \\
\hline Lip & 1.7 \\
\hline Nasopharynx & 1.7 \\
\hline Tongue & 0.8 \\
\hline \multirow{2}{*}{ Oral } & 0.8 \\
\hline & Salivary glands & 0.5 \\
\hline & Nasal, sinuses & 0.5 \\
\hline Hypopharynx & 0.4 \\
\hline Tonsil & 0.3 \\
\hline Oropharynx & 0.1 \\
\hline Pharynx NOS & 0.1 \\
\hline
\end{tabular}

* Cases per 100.000 people.

\begin{tabular}{|l|c|}
\hline KEAH 2008-2012 & $\mathbf{\%}$ \\
\hline Larynx & 12.6 \\
\hline Thyroid & 11.1 \\
\hline Lip & 7.8 \\
\hline Nasopharynx & 3.1 \\
\hline Nose, sinuses etc. & 2.7 \\
\hline Tongue & 2.5 \\
\hline $\begin{array}{l}\text { Connective and } \\
\text { oft tissue of H\&N }\end{array}$ & 2.3 \\
\hline Hypopharynx & 1.8 \\
\hline Tonsil & 1.5 \\
\hline Eye & 1.4 \\
\hline Parotid Gland & 1.3 \\
\hline Salivary glands & 0.9 \\
\hline Mouth & 0.7 \\
\hline Other oropharynx & 0.7 \\
\hline
\end{tabular}

\begin{tabular}{|l|c|}
\hline Turkey 2009' & $*$ \\
\hline Thyroid & 18.6 \\
\hline Oral. Pharynx & 2.8 \\
\hline Nasopharynx & 0.8 \\
\hline Tongue & 0.5 \\
\hline Oral & 0.5 \\
\hline Salivary glands & 0.4 \\
\hline Larynx & 0.4 \\
\hline Lip & 0.3 \\
\hline Hypopharynx & 0.2 \\
\hline Nasal, sinuses & 0.2 \\
\hline Tonsil & 0.1 \\
\hline & \\
\hline & \\
\hline & \\
\hline
\end{tabular}

\begin{tabular}{|l|c|}
\hline KEAH 2008-2012 & \% \\
\hline Thyroid & 45.3 \\
\hline Lip & 3.6 \\
\hline Nasopharynx & 2.2 \\
\hline Eye & 1.7 \\
\hline Tongue & 1.0 \\
\hline Parotid Gland & 0.9 \\
\hline Nose, sinuses etc. & 0.9 \\
\hline $\begin{array}{l}\text { Connective and } \\
\text { soft tissue of H\&N }\end{array}$ & 0.9 \\
\hline Salivary glands & 0.8 \\
\hline Hypopharynx & 0.7 \\
\hline Larynx & 0.5 \\
\hline Mouth & 0.4 \\
\hline Tonsil & 0.4 \\
\hline Trachea & 0.4 \\
\hline
\end{tabular}


11. Özkara SK, Gürbüz Y, Müezzinoğlu B, Erçin C, Yıldız K. Kocaeli bölgesinde izlenen kadın genital sistemi tümörleri (1996-2002). Türkiye Ekopatoloji Dergisi. 2003;9:17-23.

12. Bayram İ, Reçber D, İbiloğlu İ, Uğraş S. Bir patoloji anabilim dalında kanser sıklığı ve dağılımı. Ege Tıp Dergisi. 2005;44:21-7.

13. Bitiren M, Özardalı İ, Baba F, Nazlıgül Y, Eraslan H. Şanlıurfa ilinde kanser kayıtlarının değerlendirilmesi (1995-2002). Türkiye Ekopatoloji Dergisi. 2003;9:11-6.

14. Bozkurt K, Bektaş SS, Doğru N. Şırnak ilinin kanser istatistikleri. Turk Patoloji Derg. 2011;27: 230-4.

15. Baş Y, Uzbay P, Güney G, Erenler BH, Yılmaz D, Özdemir Ç. Çorum ilinde tanı konulan kanser olgularının dağılımı üzerine bir çalışma. Turk Patoloji Derg. 2014;30:118-23.

16. Köselioğlu L, Erkan C. 15471 Malign tümör vakasının istatistik değerlendirilmesi. Sağlık Dergisi. 1977;52:29-43.

17. Eser S, Eser G. Kanserden ölümün Türkiye’deki durumu. İstanbul Tip Fakültesi Mecmuası. 1964;27:125-41.

18. Karagöz F, Yıldız L, Barış S, Özdamar Ş, Bakırtaş M, Aydın O. Ondokuz Mayıs Üniversitesi Tip Fakültesi 1991-1996 yılları kanser istatistikleri. OMÜ Tip Dergisi. 1998;15:324-9.

19. Kandiloğlu AR, Postacı H. SSK Buca Eğitim Hastanesi Patoloji Bölümünde incelenen materyal içerisinde kanser sıklığı ve dağılımı son iki yılda incelenen 30671 materyalin değerlendirilmesi. Ankara Patoloji Bülteni. 1995;12:74-8.

20. Aydın Ö, Polat A, Düşmez D, Eğilmez R. Mersin ilinde kanser sıklığı ve dağılımı üzerine bir çalışma. Turk Patoloji Derg. 2000;16;48-52.
21. Ecirli Ş, Borazan A, Tek B, Deveci A, Polat H. Selçuk Üniversitesi Tip Fakültesi Eğitim ve Araştırma Hastanesine 1993-99 yılları arasında kabul edilen hastalar arasında erişkin kanser vakalarının değerlendirilmesi. T Klin J Med Sci. 2002;22:349-53.

22. Alıcı S, İzmirli M, Doğan E. Yüzüncü Yıl Üniversitesi Tip Fakültesi Tibbi Onkoloji Bilim Dalına başvuran kanser hastalarının epidemiyolojik değerlendirilmesi. Türk Onkoloji Dergisi. 2006;21:87-97.

23. Özekinci S. Patoloji Arşivindeki 10 yıllık kanser (1991-2000) olgularının genel değerlendirilmesi. Dicle Tip Dergisi. 2007; 34:164-9.

24. Haydaroğlu A, Bölükbaşı Y, Özsaran Z. Analysis of cancer registration data in Ege University: Evaluation of 34134 cases. Türk Onkoloji Dergisi. 2007;22:22-8.

25. İzmirli $M$, Altın S, Olcum B, Ünsal M. Cancer statistics of SSK Okmeydanı Training and Research Hospitals Department of Oncology from 1999 to 2004. Türk Onkoloji Dergisi. 2007; 22:172-82.

26. Arıca S, Nazlıcan E, Özer C, Şilfeler DB, Arıca V, Özgür T, Özaydın Ü. The frequency and distribution of cancer cases in Hatay District in 2008. J Clin Exp Invest. 2011;2:192-5.

27. Taşdemir E, Demir C, Dilek İ, Atmaca M. Van ili ve çevresinde malign tümörlerin dağılım sıklığı. Van Tip Dergisi. 2010;17: 114-7.

28. T.C. Sağlık Bakanlığı sağlık istatistikleri yıllığı 2010. Ankara: Kalkan Matbaacılık; 2011.

29. T.C. Sağlık Bakanlığı Sağlık İstatistikleri Yıllığı 2012. Ankara: Sentez Matbaacılık ve Yayıncılık; 2013. 